\title{
Historical Psychology, Utopian Dreams and Other Fool's Errands
}

\author{
Nick Hubble
}

Criticism must be allowed the right to judge and condemn the artistic products of entire periods, while acknowledging their social-historical necessity. ${ }^{1}$

The initial premise of Georg Lukács's The Historical Novel is well-known and can be found outlined in its opening sentence: "The historical novel arose at the beginning of the nineteenth century at about the time of Napoleon's collapse (Scott's Waverley appeared in 1814)" (15). According to Lukács, the classical historical novel inaugurated by Sir Walter Scott was distinguished from what had preceded it by the conscious employment of a historical sense, already implicitly present in the realist fiction of Smollett and Fielding, combined with an understanding that progress is driven by the conflict of social forces. It was distinguished from the anti-fascist humanist historical fiction of Lukács's own time - the book was completed at the high point of the Popular Front in 1937 - by its production of "the concrete prehistory of the destiny of the people themselves" as opposed to a mere "abstract prehistory of ideas" (408). In between times, the genre had reached its nadir in the second half of the nineteenth century as it became an empty shell, exemplified in the manner by which Flaubert's description of objects in Salammbô "overwhelms the portrayal of the men themselves" (221). The closing paragraph of the The Historical Novel concludes:

This historical novel of our time, therefore, must above all negate, radically and sharply, its immediate predecessor and eradicate the latter's traditions from its own work. The necessary approximation to the classical type of historical novel which occurs in this connexion will, as our remarks have shown, by no means take the form of a simple renaissance, a simple affirmation of these classical traditions, but, if one will allow me this phrase from Hegel's terminology, a renewal in the form of a negation of a negation. (423)

The crucial point here, before any evaluation of Lukács's analyses, is that his anticipated outcome did not materialise: the anti-fascist Popular Front did not give rise to a renewed form of the historical novel. The question from Lukács's own critical perspective, therefore, is where did he go wrong?

It hardly needs saying that Lukács was no crude Marxist. The handful of uncritical paeans to the Soviet Union which appear in the closing pages of The Hostorical Novel may be ascribed to the 'social-historical necessity' of the time; the book was, after all, written during exile in Moscow. Therefore, while he argues that "within capitalist society the class struggle of the proletariat gives birth to aims which directly unite the individual and the social" (175), he takes pains to point out that this struggle is played out across the totality of society and that concentration on one or other of the "two nations" necessarily leads to impoverished literature (247). The interaction of social forces is always many-sided and creates "an even richer and more differentiated many-sidedness of response in the lives of the masses" (249). The strength of the classical historical novelists lay in their ability to do justice to this richness and complexity of popular life. Unfortunately, by the time of the Popular Front, serious writers had become alienated from society and thus their vision had become reduced to one or other of the abstract categories of the "two nations": bourgeoisie or proletariat. The key moment of historical transition for Lukács was the revolution of 1848, when the first major clash between proletariat and bourgeoisie hitherto broadly allied against the remnants of the feudal state - triggered the collapse of "revolutionary democracy into compromising liberalism” (202). The idea of progress as complex and contradictory was supplanted by the idea of straightforward social evolution, embodied in "the 
new science of sociology" (206), and the question of uniting individual and society came to appear simply a matter of functional fit. Lukács's main objection to this transition is that it entailed the reduction of the "immediate forms of existence of human life" into "fetishistic abstractions" (3545). To paraphrase his argument, one does not need to be a Marxist to see the world differently from bourgeois sociologists: "Defoe or Fielding, Scott or Cooper, Balzac or Tolstoy in most cases grasped this living side of economy correctly and deeply” (355). The abiding value of The Historical Novel lies in the description of the achievement of these writers in successfully representing the complexity and totality of society. In particular, it is through his close reading of Scott that Lukács is able to disclose his perfect model for the relationship between aesthetics and history:

Scott's greatness lies in his capacity to give living human embodiment to historical-social types. The typically human terms in which great historical trends become tangible had never been so superbly, straightforwardly and pregnantly portrayed. And above all, never before had this kind of portrayal been consciously set at the centre of the representation of reality. (34-5)

The problem with The Historical Novel, then, is not Lukács's insistence that bourgeois prose began to fail in the second half of the nineteenth century because it could not connect with "the rancour and indignation of the broad masses of the people whose real desires remained unfulfilled by the bourgeois revolutions from 1789 to 1848” (246) in the same way as Scott and the other authors listed above, but rather the fact that Lukács, himself, falls foul of his own diagnosis and loses touch with the desires of popular society. This can be seen most clearly from the obtrusive normative discourse which surfaces periodically throughout his account. For example, in a digression on John Ford's 'Tis Pity She's a Whore, Lukács states that the incestuous passion at the centre of the play is too "humanly foreign" for an audience to possibly sympathise with, before claiming that the subject is "too eccentric, too subjective to be able to carry a dramatic action" (130-1). He goes on to ascribe the increased focus on the "physical-sexual side" of love from the second half of the nineteenth century onwards to the separation of the bourgeoisie from revolutionary democracy and decries the vicious circle by which "writers are forced to search for more and more exquisite, abnormal, perverse, etc., themes in order to escape monotony" (230). Most tellingly, he bemoans how "economics itself turns into an analysis of economic notions rather than the objective facts of production (theory of marginal utility)" (210). However, it is simply a fact that classical political economy became increasingly unable to account for the value of commodities as mass popular markets developed during the second half of the nineteenth century. Value was clearly not a function of utility judged in some absolutist sense but of marginal utility - the utility to the consumer of one additional unit ${ }^{2}-$ or, in other words, value was a function of the desires of individual consumers. Consumer society allows subjective desires to be realised materially and therefore has a genuinely popular element. Although popular society and consumer society are not the same thing, it is impossible to remain in touch with the former while rejecting the latter out of hand. It is Lukács's dogmatism on this point, which indirectly contributes to the major critical misjudgement in The Historical Novel:

What Marx said of legal institutions applies in wide measure to literary forms. They cannot stand higher than the society which brought them forth. Indeed, since they deal with the deepest human laws, problems and contradictions of an epoch they should not stand higher - in the sense, say, of anticipating coming perspectives of development by romanticUtopian projections of the future into the present. For the tendencies leading to the future are in fact more firmly and definitely contained in what really is than in the most beautiful Utopian dreams or projections. (421)

Lukács's attempt to isolate the materialist desires of the masses as the true revolutionary impulse by excluding sexual and consumer desires, results in his rejection of an alternative, and more inclusive, model for revolutionary desire: utopian dreaming. In Archaeologies of the Future: The Desire Called Utopia and Other Science Fictions, ${ }^{3}$ Fredric Jameson makes the case that charting 
the complexity and totality of society requires paying as much critical attention to utopian dreams of the future as to concrete prehistory:

Utopia is philosophically analogous to the trace, only from the other end of time. The aporia of the trace is to belong to the past and present all at once, and thus to constitute a mixture of being and not-being quite different from the traditional category of Becoming and thereby mildly scandalous for analytical Reason. Utopia which combines the not-yetbeing of the future with a textual existence in the present is no less worthy of the archaeologies we are willing to grant to the trace. (xv-xvi)

In the same manner that Lukács privileges the literary genre of the historical novel for revealing the concrete prehistory of society, Jameson privileges the literary genre of science fiction for revealing the utopian dreams of the future on its emergence "virtually full-blown, with Jules Verne and H.G. Wells, during the second half of the nineteenth century" (284). In both cases a new cultural consciousness arose combined with "the emergence of a narrative form peculiarly restructured to express that new consciousness” (284). In addition, Jameson argues that these two processes are causally linked by pointing out that the moment of Flaubert's Salammbô, when, "emptied of its vitality," the historical novel ceases to function as a genre, "is also the moment of the emergence of SF, with the first novels of Jules Verne” (285). He concludes:

We are therefore entitled to complete Lukács's account of the historical novel with the counter-panel of its opposite number, the emergence of the new genre of SF as a form which now registers some nascent sense of the future, and does so in the space on which a sense of the past had once been inscribed. (285-6)

This is not just a case of reading Lukács’s logic against his ostensible argument, for there is, in at least one part of The Historical Novel, an aside which half opens the door to exactly the kind of analysis Jameson makes. In a passage explaining why revolutionary progress cannot be equated with the cause of the proletariat, Lukács notes that "Lenin also pointed out that in all spheres of life there also existed a petty-bourgeois democratic opposition to imperialism, to its antidemocratic tendencies" (304). Verne and, especially, Wells - the son of a shop keeper and a domestic servant - can be seen as articulating exactly such a petty-bourgeois opposition to imperialism. Moreover, their position evaded the ideological pitfalls of seeking to turn back history from monopoly capitalism to free trade because they sought escape into the future: pettybourgeois individualism would not necessarily be reactionary in a post-scarcity society which met the material demands of all its inhabitants. ${ }^{4}$

However, science fiction can be seen, like the historical novel, as a genre which gradually ceases to function in its original manner. Jameson remarks that "what is original about Lukács's book is not merely this sense of the historical meaning of the emergence of the new genre, but also and above all a more difficult perception: namely of the profound historicity of the genre itself, its increasing incapacity to register its content” (285). Likewise, Jameson's book demonstrates a subtle perception of the historicity of science fiction, which follows from his argument that "the most characteristic SF does not seriously attempt to imagine the "real" future of our solar system. Rather ... . [it] transform[s] our own present into the determinate past of something yet to come" (288). That is to say that the 'content' of the science fiction of Wells and Verne was not the future, whatever technological marvels they portrayed, but the present apprehended as history. It was this content which was gradually lost as the genre began to harden into accounts of inevitable technological progress. Whereas an editorial in the first issue of Hugo Gernsback's Amazing Stories in 1926 extolled "the Jules Verne, H.G. Wells and Edgar Allen Poe type of story - a charming romance intermingled with scientific fact and prophetic vision", by the 1938-46 'Golden Age of SF', ${ }^{6}$ readers were being invited to identify, according to Roger Luckhurst, as "the elite engineers of imperial history, who transcend the pettiness of everyday existence with uncanny scientific predictive power". ${ }^{7}$ Luckhurst concludes that the logical consequence of this trajectory was the Dianetics of Golden-Age writer L. Ron Hubbard (73-5). 
If a certain type of SF ran into a dead end around the middle of the century, this was no different to the fate which befell another literary genre which also grew out of the collapse of the historical novel: modernism. James Joyce's Finnegans Wake (1939) may also be viewed simultaneously as high point and end point of its particular literary trajectory. As Orwell wrote in 1944, even if the book succeeds in cramming in the entire human race it does so at the cost of individuality: "the words have finally won. There is no emotional interest, and no attempt at any, and the entire book is written in a private language which Joyce has evolved by telescoping together the words of many tongues, living and dead." despite his qualification that "in fifteen years it will be either intelligible or forgotten" (111), judgement remains suspended. One way of accounting for this curious status of being simultaneously unforgettable and unintelligible would be to see the book as the final expression of one strand of modernism's increasing incapacity to register its own content. It is irrelevant that such readings - whether of SF or modernism - are necessarily always partial and subjective to some degree: the point - the very point which Lukács made so trenchantly, as quoted at the beginning of this essay - is that any conceptual framework employing periodisation depends on exactly such readings.

However, it is possible to go further and argue that the trajectories of 'Golden-Age' SF and 'high' modernism are not merely analogous literary processes but closely-linked parallel products of the collapse of the historical novel. The relationship between the two fits the distinction Marshall Berman makes in All That Is Solid Melts Into Air between pastoral-modernism - a "faith in the bourgeoisie neglect[ing] all the darker potentialities of its economic and political drives" and counter-pastoral modernism - the intransigent aesthetic opposition of modern artists, apparently "float[ing], untouched, freely above [the modern world]." ${ }^{\text {"9 }}$ Berman sees these two versions of pastoral as structuring a persisting division of responses - "modernolatory" and "cultural despair" - to a modernity understood as running from at least the mid-nineteenth century to the 1970s (the time when he was writing), and his dialectical approach privileges figures such as Goethe and Baudelaire, who freely employ both versions of pastoral and, therefore, point towards what he sees as the possibility of a modernist full consciousness. For example, he argues that Baudelaire achieves his greatest success in capturing the experience of modern life by ignoring the sirens of artistic purity and so combining counter-pastoral modernism with pastoral modernism:

The lesson for Baudelaire [. . .] is that modern life has a distinctive and authentic beauty, which, however, is inseparable from its innate misery and anxiety, from the bills that modern man has to pay ... he becomes suddenly serious and cuts sharply from a patronizing certainty that the modern idea of progress is illusory into an intense anxiety over the possibility that this progress is real. There follows a brief and brilliant meditation on the real terror that progress creates: 'I leave aside the question of whether, by continually refining humanity in proportion to the new enjoyments it offers, indefinite progress might not be its most cruel and ingenious torture; whether [. . .] it would not turn out to be a perpetually renewed form of suicide, and whether [. . .] it would not be like the scorpion that stings itself with its own tail - progress, that eternal desideratum that is its own eternal despair.' Here, Baudelaire is intensely personal, yet close to universal. He wrestles with paradoxes that engage and enrage all modern men, and envelop their politics, their economic activities, their most intimate desires, and whatever art they create. This sentence has a kinetic tension and excitement that re-enacts the modern condition it describes [...]. (142-2)

On this reading, 'Golden-Age' SF and 'high' modernism can be seen both as particular competing incarnations of the ongoing division in the response to modernity and as necessarily partial responses to that modernity, hence increasingly incapable of registering their own content, because of their equal failure to transcend the divide in the manner of a Baudelaire. Yet if Baudelaire's notion of progress as eternal despair truly captures the spirit of modernity, then the partial stance of certain literary movements is at least explicable as attempted self-preservation. Indeed, Berman himself displays something akin to masochism in his willingness to embrace the paradoxes of modernity from the Faustian 'tragedy of development' - that once started, the 
development has to be continuous or all will be lost (see 38-86) - to the unflinching conclusion of his own book: "I believe that we and those who come after us will go on fighting to make ourselves at home in this world, even as the homes we have made, the modern street, the modern spirit, go on melting into air" (348). Of course, his point is that there is no escape from the ceaseless dialectic of modernity, only the possibility of creating "new modes of modernity, in which man will not exist for the sake of development, but development for the sake of man" (86). It is apparent, however, that this kind of position is always subject to collapse into despair or worse. Even American belief in progress has now fragmented in the wake of 9/11 as evidenced for example by the award of the 2007 Pulitzer Prize for fiction to Cormac McCarthy's beautiful but utterly bleak parable of post-apocalyptic horror, The Road. McCarthy's novel brings to mind Lukács's comments in The Historical Novel on "the paradox whereby lofty and sensitive writers, in both an aesthetic and a moral respect, like Flaubert and [Conrad Ferdinand] Meyer, were driven to such cruelty in their writing” (280). Lukács goes on to suggest that such writers - amongst whom he includes Baudelaire - only succeed, for all their intellectual and human qualities, in giving artistic expression to the "warped and disavowed" unconscious feelings of the average bourgeois or petty bourgeois of the period. The reason for this - which can also be applied to McCarthy in the present - is "the loss of an inner relationship with history" implicit within Scott's technique of giving living human embodiment to historical-social types. Without the idea of the existence of a still space at the heart of the ceaseless dialectic forming a solid base for agency, there can be no belief in ordinary people being able to make history and the way is opened for fear and brutality.

Berman roots the overall argument of All That Is Solid Melts Into Air - that everyone is now subject to their own Faustian drive for development so that not only can Faust help make them fully conscious of modernity through dramatising the paradoxes of their existence, but that, precisely because the situation of the exceptional hero has now been universalised, the challenge of Faust concerning the need for a new mode of modernity has also been universalised - by claiming that Faust derives its lasting value from its close relationship with history: "Goethe's hero and the characters around him experience, with great personal intensity, many of the worldhistorical dramas and traumas that Goethe and his contemporaries went through; the whole movement of the work enacts the larger movement of Western society” (39). According to Lukács, Goethe's earlier work was a direct influence on Scott, but Scott's particular extension of this influence was the significant factor in the development of the historical novel. Therefore, while Goethe, aided by the experience of the French Revolution, was able to show how human greatness is liberated by the historical crises of popular life, it was Scott, in his accounts of the sudden blazes of heroism among artless, average people, who brought out "the historical character of this heroism, the peculiar historical quality of the human grandeur which it expresses" (55). So that while both "these great writers" lay bare the human potentialities "widespread among the popular masses", Goethe sources these from a generalised psychology - a kind of refined version of folk wisdom - while Scott shows the precise social-historical features which form "the specific character of the naïve and grand heroism” of a popular figure such as Jeanie Deans in The Heart of Midlothian (see 55-7). As Lukács goes on to observe, Goethe's later works, such as the second part of Faust, are no closer to, indeed probably further away from, achieving a concrete "historical psychology" (73). Furthermore, Faust with its exceptional hero strikes a very different emphasis from these stories of popular figures whose very non-exceptional status is signified by their recession into simple everyday life after the accomplishment of their mission (see 56-7).

It is possible from a Lukácsian perspective, therefore, to identify two major flaws in Berman's position, which are that, despite his careful delineation of various sets of historical circumstances, he only succeeds in describing a generalised experience of modernity rather than concrete historical psychologies and that he attempts to universalise an exceptional figure by arguing that everyday experience is now Faustian, rather than allow the human grandeur of everyday heroism to express itself. As a consequence, while a masochistic commitment to experience modernity always in the fullest, most paradoxical manner possible may just about hold open the possibility of a new mode of modernity among the numerous roads to damnation, it has no sure means of locating such a mode or even of positively identifying it in the unlikely event of stumbling across it. 
It should be clear from this brief account that the key concept here is that variously described by Lukács as "an inner relationship with history" or "historical psychology", by which he means a state of being in which the condition of simultaneously being driven by outer historical forces and inner psychological compulsions is not experienced as the ceaseless dialectic of paradoxical modernity that Berman locates in Goethe and Baudelaire, but rather as a concurrent point of equilibrium on which the world can be made to turn. For Lukács, of course, the significance of Scott was that he innovated the representation of such "historical psychology" and thus can be seen as the 'Author' - in the Foucauldian sense - of the genre of historical novels. Scott drew on Goethe, as we have seen, but both men drew on the inherent potential of fictionality generated by the rise of the novel during the eighteenth century. The training offered by the novel in disbelief, speculation and fabulation can be viewed as the origin of modern subjectivity, as argued by Catherine Gallagher: "Indeed, almost all of the developments we associate with modernity - from greater religious toleration to scientific discovery - required the kind of cognitive provisionality one practises in reading fiction, a competence in investing contingent and temporary credit." ${ }^{10}$ It was within this space pregnant with cognitive provisionality that the French Revolution detonated. Both Goethe and Scott showed the human potentiality liberated by this combination and by so doing helped generate the awareness of possibility that characterises modernity. However, it is the very existence of this awareness which generates and perpetuates the experience of modernity as endless crisis because it breaks down within the duality of the post-enlightenment rational mind into the either/or of mind vs. matter. Scott's singular achievement was to show how this either/or could be circumvented by using a non-linear type of logic in which rather than A being itself and not B, it can be both itself and B simultaneously. Normally, heroes are not ordinary people and if ordinary people are discovered to be heroes, they cease to be ordinary anymore, but Scott's Jeanie Deans is simultaneously hero and ordinary person. The place where these kinds of conflicting desires - to be an ordinary person and a hero, or, specifically in Jeanie Deans's case, not to perjure herself but still save her sister from execution - can be simultaneously met is in dreams: effectively, the psychological element in Lukács's descriptive term "historical psychology". The historical element is generated by situating the present - of the novel - in the past and thereby generating a future perspective and with it the means of escaping the endless present of the crisis of modernity. The combination of the two elements creates the equilibrium which enables ordinary human beings to act as historical agents.

It is this sense of transition, which - as we have seen - Lukács characterised as the production of "the concrete prehistory of the destiny of the people themselves", that prevents the historical novel of Scott appearing as just another version of pastoral similar to those identified by Berman. Berman employs what Raymond Williams describes as "the ordinary modern meaning of pastoral”, which is descended from the eighteenth-century appropriation of allegorical forms of pastoral as a mode of representation for concealing the true social relations of agrarian capitalism. ${ }^{11}$ That concealment depended on the same set of components simultaneously representing a social order and a natural order and, thereby, rendering the social as apparently natural. On this reading, the enabling factor for modern versions of pastoral is the presence of the kind of non-linear dream logic which will allow A to be both itself and B simultaneously. It is because Berman considers that a similar logic - modernity experienced as simultaneously the awareness of the possibility of change from tradition into something better and the awareness that this change is ceaseless, thereby allowing no stable state to be achieved - underlies both modernolatory and cultural despair, that he labels them pastoral-modernism and counter-pastoral modernism. Both these versions of pastoral privilege one possible meaning of modernity and conceal the other; Berman therefore insists that a full modernist consciousness always needs to confront the experience of modernity as an unceasing paradox. By the same token, we might expect "historical psychology" to break down into two competing versions of pastoral: an historical materialism concealing individual psychological drives and a liberal humanism concealing collective historical forces. While these cultural phenomena are hardly unknown, it is their recurring and inevitable failure as explanatory systems that has provided the context for this return to Lukács's analysis, which holds true precisely because the versions of pastoral displayed in Scott's historical novels function in a different manner to that implied by Berman. 
The relevant source for understanding this type of pastoral is not Williams, but William Empson. In Some Versions of Pastoral, Empson employs a form of the dream logic which allows A to be both itself and B simultaneously, in his concept of "Comic Primness, the double irony in the acceptance of a convention". ${ }^{12}$ He describes the different levels of Comic Primness in relation to the mock-pastoral of John Gay's The Beggar's Opera. The first type can be seen in examples where the speaker apparently straightforwardly accepts conventions but in such a manner that the activities of any ordinary person remain evidently unaffected. In the second type, speakers accept conventions in a manner that implies they are wrong - as in the better known form of single critical irony - but this is compounded by the further irony that the speaker will nevertheless comply, either out of weakness or from selfish motives. In the third and full type of Comic Primness, the speaker simultaneously accepts and revolts against the convention primly adopted:

For this pleasure of effective momentary simplification the arguments of the two sides must be pulling their weight on the ironist, and though he might be sincerely indignant if told so it is fair to call him conscious of them. A character who accepts this way of thinking tends to be forced into isolation by sheer strength of mind, and so into a philosophy of Independence. (171)

The essay on 'Proletarian Literature' with which Empson begins his book makes it clear that he is tracing this "trick of thought” through a historical series (25). In these terms, The Beggar's Opera with its popular audience can be seen as a nodal point in the historical extension of this model form of independent agency from the restricted readership of the metaphysical poets to the potentially mass readership of proletarian literature in the $1930 \mathrm{~s}^{13}$ It is participation in an ongoing process of transition and transformation of the world that prevents the particular versions of pastoral which Empson discusses from functioning in the modern manner identified by Williams and Berman. The similarities with Lukács's position are particularly brought out in the way that Empson uncannily anticipates the discussion of Scott's use of ordinary people to express the historical quality of human grandeur when describing the trick of the pastoral figure of l'homme moyen sensual as "that he refuses to recognise the grandeur of the senses which he cannot keep out of his words” (172).

To return to Jameson's terminology, we can now think about genres capable of registering their own content as cultural forms that generate agency by combining dream logic and historical transition - rather as balance and movement are both essential for riding a bicycle - whether the result is Gay's mock pastoral as described by Empson or Scott's historical novel as described by Lukács. These qualities were also present in the genres which emerged following the historical novel's loss of the capacity to register its own content: the science fiction of Wells in which the equivalent "historical psychology" of the present is generated from the perspective of the future and modernism, in which it is generated from the perspective of the past. As suggested, these genres in turn fell off their bikes after losing their sense of psychological balance or historical transition or both. However, much as Lukács's rejection of the validity of sexual and consumer desires as expressions of popular desire led him to subsume his own insights into historical psychology within the Marxist orthodoxy of historical materialism, critical orthodoxy has had the effect of stifling these genres when what was needed was a radical return to first principles. The only one which was able to meet Lukács's call for "a renewal in the form of a negation of a negation" was science fiction and this was because it found itself another petty-bourgeois oppositional writer to match Wells: Philip K Dick.

By negating the triumphalist technological determinism of 'Golden-Age' SF, Dick restored the capacity of the genre to register its own content. Jameson argues that Dick returns to the spirit of Wells and Verne in his technique of rendering "our present historical by turning it into the past of a fantasised future", but with the significant difference that "his late twentieth-century objectworld (unlike the gleaming technological futures of Verne or Wells) tends to disintegrate under its own momentum, disengaging films of dust over all its surfaces, growing spongy, tearing apart like rotten cloth or becoming as unreliable as a floorboard you put your foot through" (345-6). At the same time: "Dick's work transcends the opposition between the subjective and the objective, and thereby confronts the dilemma which in one way or another characterises all modern literature of 
any consequence ... [by] retain[ing] possession and use of both apparently contradictory, mutually exclusive subjective and objective explanation systems all at once” (350). Jameson takes pains to point out that this utilization of dream logic is prevented from collapsing into the fantasies and dream narratives of Symbolism and Modernism by always being given a causal attribution such as drugs or schizophrenia. Thus psychology is reunited with historicity, only with the strange twist that this time material objects also gain agency by reasserting their use value. Summarising Jameson's analysis, it is possible to suggest that Dick creates a small (university) town "pastoral" (362) in which commodities, themselves, rediscover the grandeur of their being and so the possibility of a utopian future is generated that is independent of any recognisable discourse of progress and, therefore, not complicit with state systems of power. While Dick's strengths are intimately bound up (and reinforced by) his undoubted idiosyncrasies, his combination of individualism with collectivity and subjectivity with objectivity, while snubbing large scale organisation of politics or anything else, amounts to a technique of utopian revitalisation by default which was subsequently to assume a more explicit role in the genre.

One of Jameson's key examples is the Strugatsky brothers' fully self-referential Roadside Picnic: "its narrative production determined by the structural impossibility of producing that Utopian text which it nonetheless miraculously becomes" (295). Here, a radically other space, the Zone, has appeared alongside a small town and offers both magical objects and terrible risks to the 'stalkers' prepared to venture inside. ${ }^{14}$ A character in the book explains the origin and nature of the Zone using the metaphor of a picnic:

Imagine a picnic ... Picture a forest, a country road, a meadow. A car drives off the country road into the meadow, a group of young people get out of the car carrying bottles, baskets of food, transistor radios, and cameras. They light fires, pitch tents, turn on the music. In the morning they leave. The animals, birds, and insects that watched in horror through the long night creep out from their hiding places. And what do they see? Gas and oil spilled on the grass. Old spark plugs and ... apple cores, candy wrappers, charred remains of the campfire, cans, bottles, somebody’s handkerchief, somebody’s penknife, torn newspapers, coins, faded flowers picked in another meadow ... a roadside picnic, on some road in the cosmos. $^{15}$

In other words, the picnic remains have been left by aliens and we are the animal witnesses confronted by what Jameson describes as "the traces and marks of superhuman pleasure, which individual humans can hardly imagine” (75). That, nonetheless, these traces lead to a utopian glimpse of 'happiness for everybody', is a product of the pastoral structure of the book. Red, the Strugatskys' stalker protagonist, is a 'fool', an ordinary man who "kept pushing hope away, trampling on it, mocking it, trying to drink it away, because that was the way he was used to living." 16 Yet throughout he has been unable to keep the human grandeur out of his words:

You're absolutely right. Our little town is a hole. It always has been and still is. But now it is a hole into the future. We're going to dump so much stuff through this hole into your lousy world that everything will change in it. Life will be different. It'll be fair. Everyone will have everything that he needs. Some hole, huh? Knowledge comes through this hole. And when we have the knowledge, we'll make everyone rich, and we'll fly to the stars, and go anywhere we want. That's the kind of hole we have here. (36)

His hard life of grifting attains a poetic stature only during those periods when he is in the Zone, "moving quickly, but without rushing, clever and premeditatedly" (80). Here, unlike the outside world, everything always works out for him. During the final trip to the Zone to find the Golden Ball that grants wishes, he is even enabled to express the hope which he embodies. Although these words, which close the book, originate with the idealistic college student, Arthur, who is projected to be a future lawyer, cabinet minister or even president, all complicity with power structures is negated as Red sacrifices him to the "meat-mincer". Staggering down the final slope to make his wish, Red furiously reflects that he doesn't have the education or the words to express himself: "Look into my heart. You take from me what it is I want . . . it just can't be that I would want 
something bad! Damn it all, I can't think of anything, except those words of his . . . 'HAPPINESS FOR EVERYBODY, FREE, AND NO ONE WILL GO AWAY UNSATISFIED!' ’(145).

Stalker, Andrei Tarkovsky's celebrated film adaptation of Roadside Picnic, similarly privileges "God's fool" Red over the representatives of the power system, the writer and the scientist who accompany him into the Zone. According to Red, all intellectuals can think about is how to sell themselves not too cheap because the organ that people believe with has atrophied in them: "can anyone live like that?"17 Here, a dreamlike utopian difference is represented by the scenes in the Zone and those involving Red's genetically mutated daughter being shot in colour. The famous closing shot of a glass moving on the table in front of the girl indicates her telekinesis and the promise of a transfigured future.

As Jameson observes, Roadside Picnic "cannot be coherently decoded as yet another samizdat message or expression of liberal political protest by Soviet dissidents" (294) and the same also applies to Stalker. It makes more sense to view them as hybrids mixing the resources of science fiction with older European traditions, such as those of fairy tales and storytelling discussed by Walter Benjamin. ${ }^{18}$ In particular, Roadside Picnic accords with one of Benjamin's conclusions: "The liberating magic with the fairy tale has at its disposal does not bring nature into play in a mythical way, but points to its complicity with liberated man" (101). However, it is the science fiction element of Red's "hole into the future" which gives the book its peculiar historical quality and renders it a concrete, rather than abstract, prehistory of the future. Benjamin links storytelling closely to the artisan class and it is interesting to reflect how this class was subsumed into the wider lower middle classes of the late nineteenth and twentieth century, from which the science fiction storytellers such as Wells and Dick emerged. What Benjamin wrote about another member of this class, the insurance clerk Franz Kafka, can also be directly applied to Roadside Picnic: "once he was certain of eventual failure, everything worked out for him en route as in a dream" (143). As we know, Red is a fool and just as Benjamin notes that the figure of the fool in fairytales "shows us how mankind 'acts dumb' towards the myth [i.e. resists power structures]" (101), he also notes of Kafka: "Folly lies at the heart of Kafka's favourites - from Don Quixote via the assistants to the animals ... This much Kafka was absolutely sure of: first that someone must be a fool if he is to help; second that only a fool's help is real help" (142). Benjamin argues that this folly is one of the products of the decay of wisdom and that although it has squandered the substance of wisdom, it preserves its attractiveness and assurance. If wisdom is understood as the recognition that there is no such thing as human plenitude and that, therefore, agency is dependent on maintaining a state of equilibrium similar to that implied by Lukács's concept of "historical psychology", then Benjamin's account of folly can be read as an explanation for the persistence of hope in a world from which any determinate sense of history has been lost. It is possible to set out a generic formula for what might be termed the fool's errand: the fool sets out to recover human plenitude, in the knowledge that it is irrecoverable and, therefore, is certain of eventual failure but en route finds happiness at the roadside, as everything works out like a dream. It should be noted that Benjamin's work, itself, may also be read as a fool's errand.

This fool's errand structure can clearly be discerned in Kafka's The Castle. The very fact that $\mathrm{K}$. is shown to be prepared to put up with the "continual petty annoyances of life" precisely because he is striving for something incommensurably beyond any normal assessment of "an honoured and comfortable life" marks him out as seeking the unseekable. ${ }^{19}$ Yet in the context of what one character describes as "suffering under the immediate present" (195), which in Kafka's case encompassed an endless state of being somewhere on the spectrum between feudalism and fascism, what other basis for action could there be? The hope in the book coincides precisely with the belief of the little boy, Hans, that although "for the moment K. was wretched and looked down on, yet in an almost unimaginable and distant future he would excel everybody" (144). The nearest we get to the expression of this hope are the passages in which $\mathrm{K}$. lies in bed with the secretary Bürgel, half asleep in a dream state, having come unannounced as an applicant in the middle of the night, listening to Bürgel explain how it would be impossible for an applicant to come unannounced in the middle of the night and in the process revealing the heart of the heartless world of clerical bureaucracy: 
Granted if the applicant is actually in the room things are in a very bad way ... The neverbeheld, always-expected applicant, truly thirstingly expected and always reasonably regarded as out of reach - there this applicant sits. By his mute presence, if by nothing else, he constitutes an invitation to penetrate into his poor life, to look around there as in one's own property and there to suffer with him under the weight of his futile demands ... The applicant wrings from us in the night, as the robber does in the forest, sacrifices of which we would otherwise never be capable ... Nevertheless, we are happy. How suicidal happiness can be! ... With the loquacity of those who are happy one has to explain everything to him. Without being able to spare oneself in the slightest one must show him in detail what has happened and for what reasons this has happened, how extraordinarily rare and how uniquely great the opportunity is, one must show how the applicant, though he has stumbled into this opportunity in utter helplessness such as no other being is capable of than precisely an applicant, can, however, now, if he wants to, Land Surveyor, dominate everything and to that end has to do nothing but in some way or other put forward his plea, for which fulfilment is already waiting. (252-4)

That the narrative movement that allows this encounter to work out for $\mathrm{K}$. as in a dream, also generates a glimpse of utopia - a world in which bureaucrats and citizens will come together in mutual recognition and fulfilment, from each according to their abilities, to each according to their needs - suggests that the narrative production of utopia may operate in the same manner as, according to Freud, the dream work produces dreams. Utopia being directly created by dream work is the central story line of Jameson's other key example of how science fiction turned from narrating the future to narrating the impossibility of narrating the future: Ursula Le Guin's homage to Dick, The Lathe of Heaven. Here, the resonantly named George Orr, despite being "a fool, a passive nothing of a man", ${ }^{20}$ has unwanted dreams which change reality. His psychiatrist, Haber, doesn't attempt to cure him but sets out to use this power by proxy to transform the world for the benefit of humankind; but, of course, every attempted change for the good is always accompanied by some unexpected monstrous consequence. For example, when in seeking to solve overpopulation, Haber instructs Orr to dream about a world full of room to move around in, he dreams of a plague and wakes up to find that he has "obliterated six billion lives and changed the entire history of humankind for the past quarter century" (71). The trouble is, as Haber comes to realise, that Orr is not only either/or but also "both, neither ... Where there's an opposed pair, a polarity, you're in the middle; where there's a scale, you're at the balance point" (118). He is the point on which the world turns, but with no sense of transition he is, again in Haber's words, "a moral jellyfish" who can only dream "cheap utopian concepts, or cynical anti-utopian concepts perhaps" (126-7). It is difficult not to read this as an intertextual comment on George Orwell - in one of the book's many alternate histories, the US Constitution is rewritten in 1984 to form a police state (93) - but it is important to remember that the fool is able to resist power structures, by acting dumb if necessary, which is what Orr is doing here in resisting Haber's will to progress. In the end, it is this resistance itself which generates its own sense of transition as when, in response to Haber's demand for world peace, Orr dreams that aliens have landed on the moon thus uniting the people of the Earth in opposition, and then, when commanded to dream that the aliens leave the moon, Orr dreams that they invade Earth - on "April Fool’s Day" (98) no less! The telepathic aliens teach Orr that "Everything dreams ... Rocks have their dreams, and the earth changes ... A conscious mind must be part of the whole, intentionally and carefully - as the rock is part of the whole unconsciously" (143). This sets up the final twist of the novel, in which Haber, having convinced himself that he can dream effectively with the aid of the Augmentor he has developed and thus bring progressive change to the world without sabotage, first gets Orr to dream that he is normal so that he can no longer effectively dream, before starting to dream himself. As he dreams, buildings begin to melt and the landscape visibly alters: "The funicular was crossing the river now, high above the water. But there was no water. The river had run dry ... They swung rapidly over the dissolving city, low enough to hear the rumbling and the cries" (146). Orr, alone, remains unaffected because his middle-of-the-scale normality means he is still at the point of perfect balance and, therefore, he is able to walk through the ensuing nothingness - "an unquantifiable entity without qualities, into which all things fell and from which nothing came forth” (147) - and 
switch off the Augmentor, thus bringing the ceaseless dialectic of modernity to a shuddering halt. What is left are mutant but benign 'suburbs of chaos':

Orr returned to downtown Portland by boat. Transportation was still rather confused; pieces, remnants, and commencements of about six different public-transportation systems cluttered up the city. Reed College had a subway station, but no subway; the funicular to Washington Park ended at the entrance to a tunnel which went half way under the Willamette and then stopped. Meanwhile, an enterprising fellow had refitted a couple of boats that used to run tours up and down the Willamette and Columbia, and was using them as ferries on regular runs between Linnton, Vancouver, Portland, and Oregon City. It made a pleasant trip. (153)

The resultant version of utopia is somewhat like Dick's small town pastoral, in which Orr, no longer plagued by effective dreams, works for an alien designing kitchenware. This meets what Lukács describes in The Historical Novel as the "epic requirement” for popular figures or ordinary heroes to return to everyday life after the completion of their "mission" in order to emphasise how the heroic attributes do not belong to the individual but "are always dormant in the people" (56-7). However, it should also be noted that Orr remains the point on which his world turns but so is everyone else in this ongoing condition of fruitful chaos, which combines individuality with collectivity.

It may be suggested that the peculiarly muddled utopian resolution of the book reflects the jumbled ideas expressed in it. Jameson distinguishes between the book's ideological and aesthetic levels:

The ideological content of Le Guin's novel is clear, although its political resonance is ambiguous: from the central position of her mystical Taoism, the effort ... to transform society in a liberal or revolutionary way is seen ... as a dangerous expression of individual hubris and a destructive tampering with the rhythms of 'nature'. Politically, of course, this ideological message may be read either as the liberal's anxiety in the face of a genuinely revolutionary transformation of society or as the expression of more conservative misgivings about the New Deal-type reformism and do-goodism of the welfare state.

On the aesthetic level . . . this book is "about" its own process of production, which is recognised as impossible: George Orr cannot dream Utopia; yet in the very process of exploring the contradictions of that production, the narrative gets written, and "Utopia" is "produced" in the very movement by which we are shown that an "achieved" Utopia - a full representation - is a contradiction in terms. (293-4)

It is this combination of political ambiguity and contradictory structure, along with its content, which gives The Lathe of Heaven particular value in foregrounding the role of dream work in utopian texts and fool's errands. For example, taking the matter of structure first, while it might appear paradoxical that utopia is produced by the very movement which demonstrates the impossibility of achieving it, the concept is much easier to accept if utopia is considered a type of dream. Dreams are produced by exactly the movements which demonstrate the impossibility of fulfilling the underlying wish provoking them, while still managing to satisfy that wish in a distorted way. Or, in Freudian terms, the dream work distorts - by processes of condensation, displacement and secondary revision in the interests of ego defence - the latent dream thoughts into the manifest content of the dream. Analytical interpretation, on the other hand, "proceeds in the contrary direction ... . endeavour[ing] to arrive at the latent dream from the manifest one". ${ }^{21}$ As far as the point of interpretation is to uncover what is wrong with the patient and thereby help them to an accommodation with reality, The Lathe of Heaven is, on one level, quite orthodox: interpretation of the effective dreams suggests there is something wrong with latent reformist desire and the cure is for people to accommodate themselves to the messiness of reality.

However, such a reading obscures the rather more fundamental point that Le Guin's fictional conceit of dreams coming true reverses the central Freudian precepts because by privileging the manifest content over the latent content of the dream, it is necessarily implying that it is the dream 
work rather than the work of interpretation which leads to an accommodation with reality - in this case, some form of Taoist dream state. The problem now becomes one of how to construct the correct latent dream thought in order to generate the required manifest content for the dream, which can be more generally expressed, as Jameson puts it, by the question of "how to fulfil a wish" (72). Viewed from this perspective, the novel once again appears less helpful because the dichotomy between Haber's wishes for a better world always going wrong and Orr's wishes to be normal eventually resulting in a small scale utopia, seems rather too simple - or, indeed, ideological - to provide a model that can be replicated. Here, though, it is useful to remember Slavoj Žižek's point that the basic matrix of the dream work is often misunderstood because a distinction has to be made between "the latent dream thought and the unconscious desire articulated in the dream: in the dream-work, the latent thought is ciphered/displaced, but it is through this very displacement that the other truly unconscious thought articulates itself". ${ }^{22}$ Once this is considered, it can be seen that the significant difference between Haber and Orr lies between their truly unconscious desires. It is Haber's own unconscious desires that distort his wish for a better society and one can interpret them from the book as a violent hatred of difference - for example, when he commands Orr to dream a solution to the "colour problem", the result is that everyone in the world turns the same shade of grey (111) - and, by extension, a violent hatred of stimuli equating to the death drive. The real question of the book, then, is what are the unconscious desires of Orr that distort his wish to be normal into the concluding utopia, given that the implied Taoist argument does not constitute a sufficient cause in terms of the dream-work structure of the book. One possible answer is that he is driven by a desire for happiness, which because of the demands of everyday life remains otherwise unacknowledged except by the occasional failure to keep a sense of human grandeur from his words.

Following on from Benjamin's argument and the examples of Roadside Picnic, The Castle and The Lathe of Heaven, it is now possible to construct a structural argument as to how the fool's errand functions. The model for this argument is Žižek's claim that "temporally and logically, the Hamlet narrative is earlier than the Oedipal myth" (11). Temporally, the basic narrative of the evil brother killing the king and the son playing the fool to survive the rule of his uncle is older than the explicit form of the Oedipal myth. Logically, although the standard psychoanalytical reading would suggest that in Hamlet the Oedipal desires for incest and patricide are distorted and displaced into a form reflecting the moral shift from antiquity to modernity, Žižek argues that the mechanism of unconscious displacement works differently: "something that is logically earlier is perceptible only as a later, secondary distortion of some allegedly 'original' narrative” (11). He goes on to suggest that the unconscious factor causing the distortion is suppressed knowledge of the triangular relationship of desire with the parents. The difference, then, is that Oedipus is able to kill his father because he doesn't know what he is doing, whereas Hamlet does know and is therefore unable to revenge his father's death. These positions can be reduced to formulae - "He doesn't know it, although he does it" and "He knows it, and therefore cannot do it" - to which Žižek adds a third: "He knows very well what he is doing; none the less, he does it" (13). This latter defines the contemporary hero, as opposed to the traditional and early modern versions, and is an ambiguous combination of knowledge and act encompassing a range of positions from low cynicism to high tragedy to something like the Kierkegaardian teleological suspension of the ethical without the leap of faith: "when a higher necessity compels me to betray the very ethical substance of my being” (14).

Following Žižek's model, we can approach the fool's errand as the secondary distortion of an allegedly "original” narrative, which rather than having a fool set out in search of plenitude and finding happiness at the roadside, instead, consists of a successful journey. According to Freud, all such journeys lead to an ancient goal: "an initial state from which the living entity has at one time or other departed and to which it is striving to return by the circuitous paths along which its development leads". ${ }^{23}$ A standard psychoanalytical reading of the fool's errand would therefore suggest that it involves a distortion of the death drive. However, given that the fool's errand is an older narrative than the death drive - Benjamin argues that storytellers borrowed their authority from death ${ }^{24}$ and without their tales of liberation there would be no state of being from which to return to the origin - an unconscious factor must be causing the distortion, and this can only be suppressed knowledge of the death drive or, rather, of that desire for plenitude which underlies the 
death drive. The difference, then, is that the 'living entity' is able to reach death without too many diversions because it doesn't know what it is doing, whereas the fool does know and is therefore liable to follow every false trail. It is the realisation of failure which shifts focus from the goal to the journey itself and the realisation that, in the words of one of Benjamin's exemplary storytellers, "to travel hopefully is a better thing than to arrive". ${ }^{25}$ This is the true state of mind of the fool in which the formula of "he knows very well what he is doing; none the less, he does it" is shown to operate in the manner of Empson's pastoral trick of thought. By simultaneously accepting and revolting against the desire for plenitude, the fool is able to hold the gap between subject and object in a productive tension that permits both some satisfaction of desire and the possibility of transferring that desire. This mobile condition of equilibrium leads the fool not towards an inanimate state, but rather into that complicity with liberated nature which Benjamin described as happiness. ${ }^{26}$

Fools, however, are not suffered gladly by capitalism and present a challenge to bourgeois concepts of the unified self. It can be imagined how the fool's errand might excite a similar response to that which Jameson describes as "the conventional repudiation of science fiction", which has nothing to do with taste or aesthetics, being instead a kind of "generic revulsion, in which this form and narrative discourse is the object of psychic resistance as a whole and the target of a kind of literary "reality principle" (xiv, footnote). While neither Kafka nor Benjamin is regarded in this light, this is because, like Surrealism, they can be contained and reduced to "a manageable literary operation already classified and catalogued in advance” (317). As the subversive energies of the Surrealists are defused by inclusion within the category of the 'irrational', so some of the more troublesome aspects of Benjamin and Kafka can be safely classified as 'religious'. However, there is one major writer of the interwar years who does provoke a generic revulsion, at least amongst the ranks of academic criticism, and that is George Orwell. A Clergyman's Daughter, Keep the Aspidistra Flying, The Road to Wigan Pier and Homage to Catalonia are all fool's errands. Nineteen Eighty-Four is an anti-fool's errand - a fool sets out to recover plenitude in the knowledge that it is irrecoverable but manages to succeed in reaching the goal in spite of himself - designed to satirise the inability of the intellectual to share the hope of the common people.

Orwell's most significant fool's errand is his 1939 novel, Coming Up for Air, in which the central character George Bowling finds the remains of a roadside picnic or, more specifically, a roadside fire and experiences a moment of happiness in a world heading inexorably towards total war:

It's curious that a red ember looks more alive, gives you more of a feeling of life, than any living thing. There's something about it, a kind of intensity, a vibration - I can't think of the exact words. But it lets you know that you're alive yourself. It's the spot on the picture that makes you notice everything else .... I know it's a good feeling to have. What's more, so does everybody else, or nearly everybody. It's just around the corner all the time, and we all know it's there. Stop firing that machine-gun! Stop chasing whatever you're chasing! Calm down, get your breath back, let a bit of peace seep into your bones. (171-3)

Bowling is the pastoral figure of the average sensual man who cannot keep a sense of human grandeur out of his words. These hopes are given a peculiar historical quality by being staged on the verge of the Second World War as a challenge to the implicit threat of a totalitarian future. In this situation the fool's errand carries a political charge as the combination of everyman hero, second person address and multiple choice ending inviting readers to work it out for themselves, extends a model of hope and agency to its readership. ${ }^{27}$ As such the book can clearly be classified as part of the intermodern project which sought to simultaneously celebrate the imaginative lives of readers and the everyday interests of the masses and so universalise agency. ${ }^{28}$

The lineaments of an alternative tradition are starting to emerge linking such apparently diverse writers as Kafka, Orwell and, by analogy, Dick, Le Guin and the Strugatskys. Obviously, at one level, the link operates through influence. Thus, while the science fiction writers read Orwell and Kafka, we also know that Orwell was reading Kafka during the planning and writing stage of Coming Up for Air. ${ }^{29}$ Benjamin suggests that the trick of Kafka's fool's errand was to bring the 
breath-taking speed of the moments of roadside happiness on the journey into line with a slow narrative pace. ${ }^{30}$ This was most perfectly achieved in a very short style piece, 'The Truth about Sancho Panza':

Without ever boasting of it, Sancho Panza succeeded over the years, by supplying a lot of romances of chivalry and adventure for the evening and night hours, in so diverting from him his demon, whom he later called Don Quixote, that his demon thereupon freely performed the maddest exploits - which, however, lacking a preordained object, which Sancho Panza, himself was supposed to have been, did no one any harm. A free man, Sancho Panza philosophically followed Don Quixote on his crusades, perhaps out of a sense of responsibility, and thus enjoyed great and profitable entertainment to the end of his days. $^{31}$

This story reveals a model for extending momentary happiness through narrative that could be applied in the external world. For instance the names Eric Blair and George Orwell can be respectively substituted for Sancho Panza and Don Quixote. So that we might say that Blair succeeded over the years, by supplying a lot of stories, in so diverting from him his demon whom he called Orwell, that his demon thereupon freely performed the maddest exploits and so on. So successful was this manoeuvre that five major biographies have been written about the demon George Orwell, while Eric Blair has remained free and thus enjoyed great and profitable entertainment even beyond the grave. As Blair-Orwell noted: "the two principles noble folly and base wisdom, exist side by side in nearly every human being. If you look into your own mind, which are you, Don Quixote or Sancho Panza? Almost certainly you are both" ${ }^{32}$ Not only does this duality allow the pastoral generation of agency that operates within the fool's errand, but it also allows writers and intellectuals to remain in touch with or even part of popular society. Lukács, rightly, saw Cervantes's Don Quixote as a model for correcting "the divorce of German writing from popular life" (411) and thus paving the way for anti-fascist writers to produce a renewed form of the historical novel; as we have seen, this transformation took place elsewhere and in different forms. Twentieth-century versions of the fool's errand may yet prefigure a general alteration of consciousness in the manner that Cervantes was an important precursor of the rise to dominance of the critical realist novel in the eighteenth century and the attendant era of revolutionary democracy.

\section{Notes}

${ }^{1}$ Georg Lukács, The Historical Novel, trans. Hannah and Stanley Mitchell (Harmondsworth: Penguin, 1981), 403.

${ }^{2}$ For an accessible discussion of marginal utility see David Trotter, The English Novel in History, 1895-1920 (London: Routledge, 1993), 12-15.

${ }^{3}$ Fredric Jameson, Archaeologies of the Future: The Desire Called Utopia and Other Science Fictions (London, Verso: 2005).

${ }^{4}$ For an account of science fiction operating as a revolutionary petty-bourgeois critique of postwar English society, see Nick Hubble, "Five English Disaster Novels, 1951-1972” Foundation, 95 (Autumn 2005): 89-103.

5 Cited in Brian Attebery, “The Magazine Era: 1926-1960" in Edward James and Farah Mendlesohn, eds, The Cambridge Companion to Science Fiction (Cambridge University Press, 2003), 33. 
6 See Peter Nicholls, "The Golden Age of sf” in John Clute and Peter Nicholls, eds. The Encyclopedia of Science Fiction (London: Orbit, 1999), 506-7.

${ }^{7}$ Roger Luckhurst, Science Fiction (Cambridge: Polity Press, 2005), 72.

${ }^{8}$ George Orwell, “Review of James Joyce by Harry Levin” in Peter Davison, ed., I Have Tried to Tell the Truth 1943-1944: The Collected Works of George Orwell, Vol. XVI (London: Secker \& Warburg, 2001), 110.

${ }^{9}$ Marshall Berman, All That Is Solid Melts Into Air: The Experience of Modernity (London: Verso, 1983), 135 and 139.

${ }^{10}$ Cited in David Trotter, 'Into the Future', London Review of Books, 22 March 2007: 32.

${ }^{11}$ See Raymond Williams, The Country and the City (London: The Hogarth Press, 1985), 21-2.

${ }^{12}$ William Empson, Some Versions of Pastoral (Harmondsworth: Penguin, 1995), 170.

${ }^{13}$ For further discussion see Nick Hubble, "Intermodern Pastoral: William Empson and George Orwell”

in David James and Philip Tew, eds. New Versions of Pastoral: Post-Romantic, Modern, and Contemporary Responses to the Tradition (Fairleigh Dickinson University Press, 2008).

${ }^{14}$ Following Chernobyl, the term 'stalker' has become popularly applied to those prepared to risk the area of radiation.

${ }^{15}$ Arkady and Boris Strugatsky, Roadside Picnic [1972], trans. A.W. Bouis, (London: Gollancz, 2007), 102-3.

${ }^{16}$ Ibid., 125.

${ }^{17}$ Andrei Tarkovsky, Stalker, (USSR: Mosfilm Studio, 1979).

${ }^{18}$ See Walter Benjamin, Illuminations, trs. Harry Zohn (Hammersmith: Fontana, 1992), 83-107.

${ }^{19}$ Franz Kafka, The Castle, trans. Willa and Edwin Muir (Harmondsworth: Penguin, 1957), 146.

${ }^{20}$ Ursula Le Guin, The Lathe of Heaven [1971] (London: Granada Publishing, 1984), 107.

21 Sigmund Freud, Introductory Lectures on Psychoanalysis, trans. James Strachey (Harmondsworth: Penguin, 1979), 204.

22 Slavoj Žižek, Did Somebody say Totalitarianism? Five Interventions in the (Mis)use of a Notion (London: Verso, 2001), 11.

23 Sigmund Freud, "Beyond the Pleasure Principle" in On Metapsychology: The Theory of Psychoanalysis, trans. James Strachey (Harmondsworth: Penguin, 1984), 310.

${ }^{24}$ Benjamin, Illuminations, 93.

${ }^{25}$ Robert Louis Stevenson, Virginibus Puerisque (1881)

${ }^{26}$ Benjamin, Illuminations, 101. 
${ }^{27}$ For a more detailed reading of Coming Up for Air in this context see Hubble, "Intermodern Pastoral”.

${ }^{28}$ See Kristin Bluemel George Orwell and the Radical Eccentrics: Intermodernism in Literary London (New York and Basingstoke: Palgrave Macmillan, 2004).

${ }^{29}$ See Orwell, Letter to John Sceats, 26 October 1938 and Davison, editorial note, in Davison, ed., Facing Unpleasant Facts 1937-1939: The Collected Works of George Orwell, Vol. XI (London: Secker \& Warburg, 2000), 226-8.

${ }^{30}$ Benjamin, Illuminations, 135.

${ }^{31}$ Quoted ibid, 138.

32 Orwell, “The Art of Donald McGill” in Davison, ed., All Propaganda is Lies 1941-1942: The Collected Works of George Orwell, Vol. XIII (London: Secker \& Warburg, 2001), 29. 